\section{Evaluation of black crust formation and soiling process on historical buildings from the Bilbao metropolitan area (North of Spain) using SEM/EDS and Raman microscopy}

\section{Abstract}

\footnotetext{
${ }^{1}$ Department of Geography, History and Archaeology, Faculty of Arts, University of the Basque Country UPV/EHU, 01006 Vitoria-Gasteiz, Basque Country, Spain.

${ }^{2}$ Department of Analytical Chemistry, Faculty of Pharmacy, University of the Basque Country UPV/EHU, P.O. Box 450, 01080 Vitoria-Gasteiz, Basque Country, Spain.

${ }^{3}$ Department of Analytical Chemistry, Faculty of Science and Technology, University of the Basque Country UPV/EHU, P.O. Box 644, 48080 Bilbao, Basque Country, Spain.

*e-mail: maite.maguregui@ehu.es phone: +34945013058
}

In the present work, several building materials suffering from black crusts and soiled surfaces were evaluated by scanning electron microscopy energy dispersive X-Ray spectrometry (SEM-EDS) and micro-Raman spectroscopy. The goal was to examine the elemental and molecular composition, the distribution on the samples and the morphology of endogenous and exogenous compounds on those black crusts and soiled surfaces. The black crusts were deposited over different building materials such as limestone, sandstone and brick that constitute a small construction called "Malacate" as well as over a limestone substrate of a cemetery gate. Both constructions are dated back to the beginning of the twentieth century. The samples of soiling were taken from the façade of a building constructed in the 1980s. The analytical evaluation allowed in a first stage the determination of the composition and the observation of the morphology of soiling and black crusts. In addition, the evaluation of the compositions of the soiling and black crusts of different grade and formation allowed the assessment of the main weathering phenomena that the buildings have suffered, which were found to be: sulfate impact, marine aerosol impact, depositions of metallic particles, crustal particulate matter depositions, carbonaceous particles, biodeterioration and vandalism.

Keywords: black crust, soiling, greenhouse acid gases, Raman microscopy, SEMEDS, Bilbao metropolitan area historical buildings. 


\section{Introduction}

The majority of heritage constructions are constituted by stone and brick materials. Their outdoor character makes them vulnerable to the atmospheric weathering phenomena (Doehne and Price 2011) and, among the effects likely to occur, the formation of black crusts and soiling are of special importance, apart from the blackening of the surfaces (Brimblecombe and Grossi 2005), because they lead to physicochemical decay and also act as a pollutant accumulator (Schiavon et al. 2004; Larseen et al. 2006; Charola et al. 2007; Barca et al. 2010; Barca et al. 2014; Ruffolo et al. 2015; ) and acting in some cases as natural passive samplers (Morillas et al. 2016a). Consequently, not only they suppose an aesthetical problem, but in some cases they can also jeopardize the integrity of a construction. In addition, these crust are prone to include or accumulate diverse microorganisms and organic compounds in its structure. Some of these microorganism can bio-synthesize large amounts of hydrated calcium oxalate (McAlister et al. 2008) or even also promote a physical stress on the building material (cracks, fissures, etc.) placed at the back of the crust. In fact, it has already been reported that the accumulation of organic pollutants leads to an increase of microorganism activity (Potgieter-Vermaak et al. 2005).

Black crust growth is due to the formation of gypsum on surfaces sheltered from water and attacked by $\mathrm{SO}_{2}$-polluted atmosphere. According to ICOMOS glossary (ICOMOS 2008), black crust is a "Kind of crust developing generally on areas protected against direct rainfall or water runoff in urban environment. They are composed mainly of particles from the atmosphere, trapped into a gypsum matrix $\left(\mathrm{CaSO}_{4} \cdot 2 \mathrm{H}_{2} \mathrm{O}\right)$ )" On the other hand, soiling is a "Deposit of a very thin layer of exogenous particles (e.g. soot) giving a dirty appearance to the stone surface. [...] With increasing adhesion and cohesion, soiling can transform into a crust" (ICOMOS 2008).

The identification of the particulate matter deposited on stone/brick surfaces plays a crucial role in the understanding of the type of weathering processes suffering or likely to be suffered by this kind of substrates (Maguregui et al. 2008). At the same time, they provide significant information about the surrounding atmosphere, reflecting indirectly the air quality, which has an important effect in the environment as well as in the human health.

The nature of the inorganic salts crystallization occurring in the black crusts and soiling 
68 has been widely studied. Works on the field focused on the study of carbon and metallic

69 particles depositions and on the characterization of the nature of metallic particles

70 deposited on black crust are increasing in the last years (Sýkorová et al. 2011, Ruffolo et al. 2015, Morillas et al. 2016a).

72 The present work reports a detailed microscopic and chemical characterization of 73 different altered stone and brick surfaces to shed light on the deterioration mechanisms 74 happening on heritage buildings due to the influence of urban polluted and coastal environments.

76 Regarding the analytical techniques used in the field of building materials analysis, noninvasive techniques based on micro-spectroscopy have gained ground in the last years. It is especially important the development carried out in the spectral mapping 79 techniques for the application on building materials that have suffered impact of 80 atmospheric pollution such as the following spectroscopic techniques: Raman 81 spectroscopy, infrared spectroscopy, micro X-Ray fluorescence spectrometry, scanning 82 electron microscopy coupled to energy-dispersive X-Ray spectrometry (SEM-EDS), 83 laser ablation inductively coupled plasma mass spectrometry (LA-ICP-MS), etc. 84 (Watson et al. 2005; Sarmiento et al. 2008; Barca et al., 2010; Barca et al. 2011; Crupi et al., 2016; Morillas et al. 2016b, Morillas et al. 2016c). Although such techniques are 86 commonly used in a non-quantitative way, they allow determining the conservation state of the materials under study in a first stage.

88 For this study, SEM/EDS and micro-Raman spectroscopy were chosen because they 89 allow obtaining the elemental and molecular composition of the compounds embedded 90 inside the crust. They also allow visualizing the black crusts appearance as well as the 91 surfaces that have suffered soiling processes. Furthermore, both techniques allow a 92 micro-invasive characterization of small samples. Moreover, by Raman spectroscopy it 93 is possible to discern between different calcium sulfate polymorphs depending on their 94 hydration states such as gypsum or anhydrite, which are of special relevance concerning 95 the degradation processes that their dissolution/precipitation cycles may imply 96 (Rodriguez-Navarro et al. 2000; Flatt et al. 2002; Espinosa-Marzal et al. 2010). The use 97 of micro-spectroscopic techniques for the study of this type of damaged layers has had 98 an increase in the last years since it provides reliable information about the composition 99 of them. 
100 In the present work, black crusts formed on sandstone, limestone and brick substrates

101 belonging to one century old constructions were sampled, as well as soiling samples

102 from an approximately 30 years old building façade. All these historical buildings are

103 located in the metropolitan area of Bilbao (Basque Country, north of Spain). For the

104 samples characterization SEM/EDS and micro-Raman spectroscopy techniques were

105 selected.

106

107 Materials and methods

108 Sampling

109 All the studied cases are from buildings located in the municipality of Getxo (Biscay,

110 North of Spain), which belongs to the metropolitan area of Bilbao (Basque Country,

111 north of Spain). The sites are in an architecturally noteworthy area situated on the coast,

112 where the Nerbioi-Ibaizabal estuary finishes. This estuary is the major industrialized

113 area with the highest population density of the North of Spain. Due to its geographic

114 situation and because of its mineral resources richness, mainly iron, since the nineteenth

115 century, this area has suffered the rapid growth of industrialization and population

116 developments with the subsequent pollution problems. These problems were mainly

117 manifested since the 1930s, but it was not until after the 1960s, when the inhabitants

118 started to be aware of them. Despite the improvement of the environmental conditions,

119 the high rates of air pollution during this period are still obvious in many building

120 surfaces of the area. In order to study if signs of this pollution are evident on different

121 kind of crusts formed on buildings, two historical buildings and a more recent one were

122 selected. In total fifteen samples have been considered for this work. All the samples

123 have been taken at around 1-1.5 meters from the ground level.

\section{Malcate building}

125 This small construction (built around 1900) is one of the remaining constructions that

126 was built to control the sewage system of Bilbao, as part of the first modern sewage

127 network of the state. It was a necessary infrastructure for the rapidly growing industrial

128 society. It was built with rich architectural elements, in terms of materials and structure.

129 In 1994, the malacate buildings were designated monumental sets of the Basque

130 Country and in 2004 this specific malacate building located in the municipality of Getxo 
131 was included inside the list of historic and architectural heritage properties from the

132 Basque Country. This building presents black crusts on sheltered areas of the three 133 materials used for its construction: limestone, sandstone and brick (see Figure 1b). All 134 these materials covered with black crust were sampled for this work. From each 135 material showing the presence of black crusts three fragments, a biggest one (around $3 \mathrm{x}$ $1363 \mathrm{~cm}$ ) and two fragments smallest (around $0.5 \times 0.5 \mathrm{~cm}$ ), were taken.

\section{The Getxo’s cemetery gate}

138 The Getxo's cementery gate as the malacate building is already included inside the list 139 of historic and architectural heritage properties from the Basque Country. This gate of 140 the beginning of the twentieth century shows black crusts compactly adhered to 141 sheltered areas of the limestone substrate. It is worth remarking that the gate is situated 142 opposite to the main rainfall direction (see Figure 1). Three sample fragments of black 143 crust (one of around $2 \times 2$ and two of around $0.5 \times 0.5 \mathrm{~cm}$ respectively) were taken from 144 these areas.

\section{Talaieta street building}

146 This construction is located in Getxo's downtown (Biscay, North of Spain). It was 147 constructed during the last decades of the twentieth century and is one of the typical 148 buildings of the area. It is under the direct influence of road traffic, marine fog and 149 potential industrial influence. The cantilever does not allow the washing of the zones 150 that it covers, promoting the concentration of soiling in this part, hence in the present 151 work was only regarded the lowest part of the building (at around $1 \mathrm{~m}$ above ground 152 level). The damaged façade is constituted by brick shaped limestones. The limestones 153 with lowest impact show a yellowish color. On the contrary, the most affected ones 154 show a grayish colour. The natural yellow hue of the stone is given by the presence of 155 iron as part of its composition. Three fragments of crusts of $3 \times 3$ (one) and $0.5 \times 0.5$ 156 (two) cm respectively were taken from the grayish affected area.

\section{Instrumentation}

158 Scanning electron microscopy X-Ray energy dispersive spectrometry 159 (SEM/EDS)One sample of each different material and location was selected for the 160 microscopic evaluation. The criteria for the election were both the quantity and the 
161 morphology, selecting in this way samples showing the major quantity of crust, and as 162 much flat as possible. All the considered samples were metallized using gold, and then studied using an EVO 40 (Carl Zeiss) SEM equipment. The elemental composition of samples was determined by an energy dispersive EDS, using an X-Max (Oxford Instruments) equipment. Data were collected at two different voltages of 20 and $30 \mathrm{keV}$ and a current of $50 \mu \mathrm{A}$ for the acquisition of images, and $200 \mu \mathrm{A}$ for the acquisition of spectra. The working distance ranged between 9 and $11 \mathrm{~mm}$. The EDS spectra were acquired and treated using the INCA software (Oxford Instruments).

The SEM analysis coupled to EDS and processed by the INCA program, permits the elemental analysis of selected particles previously seen by SEM. Furthermore, a mapping of specific microscopic areas in the samples is possible, allowing the evaluation of the distribution of these elements over the sample. Additionally, it provides semi-quantitative data in terms of weight percentages of the detected elements.

It is necessary to underline that the SEM/EDS semi-quantitative data provided in this work are just indicative and cannot be considered completely quantitative because no reference materials/standards were used to perform an empirical calibration.

\section{Micro Raman spectroscopy}

For the micro-Raman measurement of biggest crust samples, a Raman Renishaw RA 180100 spectrometer, with an excitation wavelength of $785 \mathrm{~nm}$ (diode laser) and a Peltier cooled CCD detector was used for the molecular characterization of the samples. The system was calibrated daily using the $520 \mathrm{~cm}^{-1}$ silicon line. In order to avoid thermal decomposition of samples, the laser power (150 $\mathrm{mW}$ maximum) was kept in low levels, mainly between 1.5 to $15 \mathrm{~mW}$, depending on the sample.

The spectral resolution was $4 \mathrm{~cm}^{-1}$ in the range between $3000-200 \mathrm{~cm}^{-1}$ and the spectra 186 were acquired randomly on the crusts under study by accumulating from 5 to 20 scans 187 to improve the signal-to-noise ratio. Due to a microscope lens built in the microprobe 188 (objective lenses of: $4 \times, 20 \times, 50 \times$ ) and a video-camera, a proper focusing of the laser 189 beam spot is possible (approximately 10-200 $\mu \mathrm{m}$, depending on the focusing lens). Data 190 acquisition was carried out with the Wire 3.0 software package (Renishaw, UK) and the 191 analysis of the results was performed using the Omnic V.7.2. software (Nicolet). 


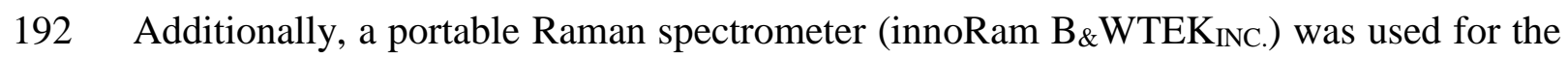
193 measurement of the smallest crust samples. This spectrometer implements a $785 \mathrm{~nm}$ 194 excitation laser source and has a variable power range up to $300 \mathrm{~mW}$. The probe offers 195 also the possibility to perform microscopic analysis mounting it on a micro-camera and 196 using different objective lenses $(20 \times$ and $50 \times)$ that allow measuring areas of a diameter 197 between 10 and $200 \mu \mathrm{m}$. In contrast to the RA 100 spectrometer, with this instrument 198 samples can be placed under the objective lens to acquire the Raman spectra. With the 199 RA100 spectrometer, samples must be placed vertically on a support to perform the 200 spectral acquisition. This sample positioning could be more difficult for small samples $201(0.5 \times 0.5 \mathrm{~cm})$, thus it was decided to measure them using the portable innoRam 202 spectrometer available in the laboratory.

203 Finally, in the cases where the $785 \mathrm{~nm}$ excitation wavelength was giving a weak Raman 204 signal, a $514 \mathrm{~nm}$ excitation wavelength $(50 \mathrm{~mW}$ nominal laser power) was used. With 205 this purpose, an inVia Renishaw confocal Raman micro-spectrometer (Renishaw, 206 Gloucestershire, UK) coupled to a DMLM Leica microscope with a variety of objective 207 lenses $(20 \times, 50 \times$, and 100x) to choose and a Peltier cooled CCD detector which 208 implements a $514 \mathrm{~nm}$ excitation wavelength laser was used.

209 The interpretation of the acquired Raman spectra was carried out by comparison with

210 the Raman spectra of standard samples that are registered in the dispersive Raman 211 spectroscopic database of e-VISNICH (Maguregui et al. 2010a) and comparing with 212 free Raman databases (e.g. RRUFF (Downs and Hall-Wallace 2002)).

\section{Results and discussion}

215

216 In the Table 1, a summary of the main results obtained for the crusts samples of the 217 three building located in the municipality of Getxo, in the Bilbao metropolitan area, 218 after the application of the proposed analytical methodology is presented. 


\section{Black crust of Malacate building}

223 Raman characterization

224 Gypsum $\left(\mathrm{CaSO}_{4}-\mathrm{H}_{2} \mathrm{O}\right)$ was the main constituent identified on the black crusts growing 225 on the three building materials from the malacate building, which can be formed as a 226 consequence of the transformation of calcite $\left(\mathrm{CaCO}_{3}\right)$ in the presence of atmospheric 227 sulfur oxide (wet or dry deposition) (Morillas et al. 2016d; Morillas et al. 2016e). 228 Moreover, several iron oxides were characterized. Hematite $\left(\mathrm{Fe}_{2} \mathrm{O}_{3}\right)$ was found on all 229 three substrates, with major presence in the case of limestone, pointing out the exposure 230 of the building to $\mathrm{Fe}$ rich particles. Moreover, magnetite $\left(\mathrm{Fe}_{3} \mathrm{O}_{4}\right)$ was also detected on 231 samples of the black crust on limestone. The size of the magnetite particles identified 232 ranges from 5-50 $\mu \mathrm{m}$. Thus, it can be considered that isolated spherules and 233 agglomerates could be present on the black crusts formed on the limestone. Magnetite 234 can be associated with atmospheric particles in the urban environment. They are mainly 235 derived from combustion processes such as industrial, domestic and vehicle emissions 236 or from abrasion products from asphalt and from vehicle brake systems (Gautam et al. 237 2005).

238 Additionally, Raman spectroscopic analysis performed in black crusts on the brick, 239 revealed the presence of a band at $1025 \mathrm{~cm}^{-1}$. Using Raman spectroscopy it has been 240 proven that iron (III) oxide is present in the original brick composition (see Raman 241 bands related with hematite in Figure 2A). The band at $1025 \mathrm{~cm}^{-1}$ can be related with 242 (para)coquimbite $\left(\mathrm{Fe}_{2}\left(\mathrm{SO}_{4}\right)_{3} \cdot 9 \mathrm{H}_{2} \mathrm{O}\right)$, which is a degradation compound formed due to 243 the attack of sulfuric acid aerosol (sulfur dioxide wet deposition) to iron oxides 244 (Maguregui et al. 2011). The atmospheric sulphur oxides ( $\mathrm{SO}_{\mathrm{X}}$ ), usually reacts firstly 245 with the ions of calcium providing gypsum and, later this gypsum starts reacting with 246 the iron oxides providing (para)coquimbite, following the reactions (1) and (2) 247 (Maguregui et al. 2010b).

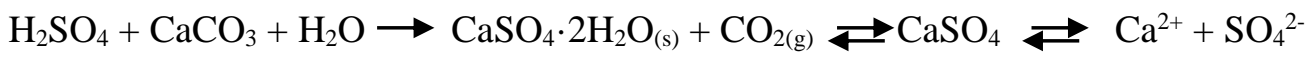

$\mathrm{Fe}_{2} \mathrm{O}_{3(\mathrm{~s})}+3 \mathrm{H}^{+}+3 \mathrm{HCO}_{3}{ }^{-}+3 \mathrm{SO}_{4}{ }^{2-}+3 \mathrm{Ca}^{2+}+6 \mathrm{H}_{2} \mathrm{O} \rightleftarrows \mathrm{Fe}_{2}\left(\mathrm{SO}_{4}\right)_{3} \cdot 9 \mathrm{H}_{2} \mathrm{O}+3 \mathrm{CaCO}_{3}$ 
252 According to this reaction, it is supposed to be normal to find (para)coquimbite together

253 with gypsum and hematite, as they are the reactants of this degradation product (see the 254 spectra in the Figure 2A).

255 It is very difficult to distinguish among Raman spectra of coquimbite and 256 paracoquimbite, because they are quite similar. Both are iron (III) sulfate non-hydrates 257 and they are also polytypes (a special kind of polymorphism, in which the two 258 polymorphs differ only in the stacking of identical two-dimensional sheets or layers).

259 The Raman band at $1025 \mathrm{~cm}^{-1}$ can be also related with $\gamma$-anhydrite $\left(\gamma-\mathrm{CaSO}_{4}\right)$ (Wein et 260 al. 2014). In the same spectrum where this band was identified, the main band of 261 gypsum is also present (see Figure 2A). This observation could also suggest that 262 gypsum is suffering a dehydration process, giving rise to the anhydrous form. Anhydrite 263 is usually crystallized as $\beta$-anhydrite. According to some authors, the environmental 264 temperature and the internal stress of the material could have influence in the 265 dehydration process of gypsum, causing the crystallization of the $\beta$ or $\gamma$-anhydrite phase 266 (Comodi et al. 2012; Prieto-Taboada et al. 2014).

267 The calcite $\left(\mathrm{CaCO}_{3}\right)$ identified in the brick can arise from the carbonation process of the 268 hydrated calcium oxide $\left(\mathrm{Ca}(\mathrm{OH})_{2}\right)$, present in the brick, which can be subsequently 269 sulfated (Maguregui et al. 2009). Calcite can also be present as a consequence of its 270 deposition on the brick as airborne particulate matter. Unfortunately, it has not been 271 possible to identify calcite on the surface of the brick. Another calcium source could be 272 the remnant calcium carbonate, which has not been completely decomposed into 273 calcium oxide $(\mathrm{CaO})$ during the firing process of the clay from the brick.

274 Furthermore, several spectra of amorphous carbon were acquired both from the 275 limestone's and sandstone's black crusts. The literature reports that in the carbonaceous 276 content appearing in the black crusts, the organic carbon fraction is usually higher than 277 the elemental fraction in most cases due to a great number of microscopically detectable 278 microorganisms and carbonaceous particles from the atmosphere including organic 279 compounds bound in the surface layer (aliphatic hydrocarbons, polycyclic aromatic 280 hydrocarbons, terpenoid derivatives, etc.) (Saiz-Jimenez et al 1991; Bonazza et al. 281 2007). 
282 Additionally, the presence of other compounds, coming from anthropogenic sources, 283 was also identified in the black crusts from limestone. These are phtalocyanine blues, a 284 phtalocyanine $\left(\mathrm{C}_{32}, \mathrm{H}_{18}, \mathrm{~N}_{8}\right)$ based compound, widely used in the dying industry. Black 285 diamond pigment, based on carbon black pigment was also detected. Both are 286 commercial pigments and were ascribed to graffitii residues. Through Raman 287 spectroscopy, burnt sienna was also identified. This is an earth pigment that takes its 288 name from the heated version of raw sienna which contains iron oxide and manganese 289 oxide (Genestar and Pons, 2005). Nevertheless, the origin of burnt sienna is not 290 completely clear, since this could be a constituent of the limestone as well, since they 291 are similar from the mineralogical viewpoint.

\section{SEM/EDS evaluation}

293 In the black crust samples from Malacate building sandstone, a smooth and compact 294 carbon layer with some pores from where the underlying gypsum crystals are 295 observable can be appreciated (see Figure 3A and 3B). Furthermore, depositions of A1296 silicates, quartz $\left(\alpha-\mathrm{SiO}_{2}\right)$, calcite and those ascribed to sea aerosol containing $\mathrm{Na}, \mathrm{Mg}$, $297 \mathrm{~K}$ and $\mathrm{Cl}$ were characterized on the surface. Concretely, in the Figure $3 \mathrm{C} \mathrm{a} \mathrm{Cl}$ particle 298 inserted in the pores of the carbon layer of the black crust can be observed (see Figure 299 3C and 3D). These finding evidences that the particles coming from the marine aerosol 300 can be deposited and trapped in the black crust matrix (Morillas et al. 2016a).

301 With regard to the limestone's black crust, carbon was not present as a smooth and 302 compact layer (see EDS carbon map in Figure S1 from Supplementary Material) like in 303 the black crust from sandstone. In this case, the contribution of calcite depositions 304 ascribed to the crustal particulate matter was observed over calcite crystals, which 305 seemed to have been recrystallized during the black crust formation. In Figure 4, 306 examples of particles deposited on the black crust can be observed. According to the 307 semi-quantitative information included in Table 2 and EDS spectral evidences presented 308 in Figure 4, not only individual particles of gypsum (see EDS Figure 4B and Table 2), 309 and calcite (see Figure 4C and Table 2) were identified on the limestone's black crust, 310 but also aggregate particles including aluminosilicates, sulfates and chlorine (see Figure 3114 A and Table 2) 
314 Black crusts of the cemetery gate

315

316

317

318 Raman spectroscopy allowed the identification of gypsum, hematite and magnetite as

319 the main components of the black crusts from the cemetery gate. Gypsum crystals and

320 hematite particles are distributed to a great extent in the black crust, indicating that this

321 building has been influenced by a highly polluted environment. Additionally,

322 carotenoids were also identified embedded in the black crusts, indicating that

323 microorganisms are included inside the matrix of the black crust. These colonizers are

324 able to excrete organic pigments, called carotenoids, or they can be present in its

325 biological structure. Only having the two main Raman bands of carotenoids it is quite

326 difficult to ascribe this Raman signal to a specific carotenoid, but as it is shown in

327 Figure S2 from Supplementary Material, this signal could belong to $\beta$-carotene.

328

329

330

331

332

333

334

335

336

337

338

339

340

341

342

343

344

345

346

347

\section{SEM/EDS evaluation}

The black crust in the cemetery gate was constituted by a matrix of gypsum crystals with depositions of carbon and random particles (see Figure 5B, where the carbon layer is highlighted in red). According to the literature, this is the most characteristic case of black crust (Moropoulou et al. 1998). The average size of the acicular gypsum crystals of the matrix (see Figure $5 \mathrm{~A}$ ) is circa $30 \mu \mathrm{m}$ long and $5 \mu \mathrm{m}$ wide.

Apart from the ubiquitous gypsum, EDS analysis performed on different particles deposited on the gypsum matrix showed that most of the particles consist mainly of aluminosilicates of $\mathrm{Ca}$ and $\mathrm{K}$ (see Figure 5C). These compounds can come from the physical and chemical weathering of soils and rocks, then being transported by the wind and finally been deposited in the façades. In atmospheric geochemistry this kind of compounds is known as crustal particulate matter (Querol et al. 2011) and comprises the $44 \%$ of global emissions of particulate matter (PM) to the atmosphere (Inza-Agirre 2010). Some of the particles (see particle 2 in Figure 5C) show the presence of $\mathrm{S}$ and $\mathrm{Cl}$ apart from aluminosilicates and most of them also contain traces of metals such as Fe, $\mathrm{Zn}$, Ti and Mn (see Figure 5C). Elements like S (from sulfates) and $\mathrm{Cl}$ (from chorides) can come from particles emitted by marine aerosol (Morillas et al. 2016e). The first element linked with sulfates can come also from anthropogenic emissions or also from 
348 calcium carbonate crustal particles that can be transformed in the atmosphere into 349 sulfates by reaction with the $\mathrm{H}_{2} \mathrm{SO}_{4}$ (coming from $\mathrm{SO}_{\mathrm{X}}$ emission) present in the acid 350 rain (Morillas et al. 2016e).

351 The length of the particles varies in the range of 5 to $15 \mu \mathrm{m}$ approximately. Apart from 352 the hazards that the pollutants can cause to the human health due to their toxicity (e.g. 353 heavy metals) their size can be also crucial as far as the hazardousness is concerned; the 354 smaller the particles are, the worse is the effect caused on human health. The $\mathrm{PM}_{10}$ particles (those sizing less than $10 \mu \mathrm{m}$ ) are more hazardous than the bigger ones, since 356 they are difficult to expel (especially from the human body). Moreover, the particles 357 below $2.5 \mu \mathrm{m}\left(\mathrm{PM}_{2.5}\right)$ are even more hazardous, since, once inhaled, they reach directly 358 the blood system (Inza-Agirre 2010; EPA 2016).

359 The composition of particle 4 in Figure 5A is given in the pie chart (Figure 5D). It gives 360 an idea of the nature of this kind of aggregates deposited on the surface. Apart from the 361 elements mentioned before, here we can see the contribution of $\mathrm{Na}, \mathrm{Cl}$ and $\mathrm{Mg}$, ascribed 362 to the chlorides coming from marine fog.

363 This is an example of how airborne particulate matter in form of deposition is mixed 364 with particles from both anthropogenic and natural sources. It cannot be predicted if the aggregate has been formed in the atmosphere, or once deposited on the gypsum matrix.

366 Nevertheless, the airborne particulate matter tends to sediment once it has reached the 367 aerodynamic diameter of $20 \mu \mathrm{m}$. Indeed, the particles with higher diameter are called sedimentable particles and they are characterized by their short time in the atmosphere, which is of about some hours (Inza-Agirre 2010). Therefore, either the source is in the proximity of the building or it has been formed once deposited, acting as a nucleation 371 point.

372

373 Soiling process of the Talaieta street building

374

\section{Raman characterization}

377 A big variety of compounds were identified in this building's samples through Raman 378 microscopy. The presence of iron oxides such as hematite (see Figure 2C) and 379 magnetite, detected in abundance, was ascribed to the deposition of particulate matter. 380 Silicates, among them quartz and feldspars, such as adularia and sanidine alkali 
381 feldspars $\left(\mathrm{KAlSi}_{3} \mathrm{O}_{8}\right)$, were also identified as particulate matter deposition and more 382 specifically as crustal particular matter. The bands between 1200 and $1600 \mathrm{~cm}^{-1}$ in 383 Figure 2D were initially ascribed to silicates in general, but there is an open discussion 384 about the topic, and the latest assumptions are that they might be fluorescence signals 385 arising from impurities that are actually in silicate matrices, but not directly resulting 386 from silicates (Gómez-Nubla et al. 2013). In fact, in a measurement acquired with a 532 387 nm laser, they should not appear for this same reason.

388 Degradation products deriving from the interaction between atmospheric pollutants and 389 the calcareous stone surface were also identified, such as gypsum and anhydrite (see 390 Figure 2D). The presence of calcium sulfates with different hydration states could 391 suggest that the hydration/dehydration cycle of gypsum-anhydrite is taking place (in this 392 case bassanite was not identified). This cycle produces tension in the material due to a 393 volume change on the stone and can promote cracks, fissures and fractures on the 394 material.

395 Apart from the exogenous compounds ascribed to degradation processes and 396 atmospheric depositions, some remains of graffiti painting were found. For instance, the 397 presence of ultramarine blue pigment was confirmed by Raman spectroscopy (see 398 Figure 2A).

399 SEM/EDS evaluation

400 At a first stage, the brownish crust present in the Talaieta street building is formed by 401 several randomly arranged particles which do not show strong cohesion as in the rest of 402 the buildings. In this case, there is not an evident gypsum crystals layer. In Figure 6A 403 and 6B, Ca, Si and S EDS maps can be observed. As can be appreciated in the overlaid 404 EDS map, $\mathrm{Ca}$ is spread over the sample whereas there is predominance in $\mathrm{S}$ over $\mathrm{Si}$ 405 matching with Ca map. Considering this, it is assumed that the crust is a mixture of 406 gypsum and silicates.

407 Different subtractions were made on the same EDS maps (in Figure 5A and 5B) 408 revealing spots with high amount of $\mathrm{Ca}$, which did not match neither with $\mathrm{S}$ nor with $\mathrm{Si}$. 409 Therefore, they were ascribed to possible calcite depositions. Furthermore, several Si 410 accumulation points were also spotted depicting possible quartz depositions. The 411 assumption of being deposited rather than belonging to the substrate is made taking into 
412 account the minimum penetration depth of the X-Ray beam of the EDS.

413 EDS spectra indicate a high input of metallic airborne particulate matter. Al, Ca, Fe, K,

$414 \mathrm{Ti}, \mathrm{Zn}, \mathrm{Cu}, \mathrm{Pb}, \mathrm{Cr}, \mathrm{Mn}$ and $\mathrm{V}$ were identified. Among them, titanium particles were the

415 most abundant, regularly accompanied by $\mathrm{Fe}$ and traces of $\mathrm{Pb}$ and $\mathrm{V}$ (see Figure 6F).

416 Apart from the Al-silicates encountered repeatedly among the EDS analysis, EDS 417 spectra, acquired on the particle circled in Figure 6D of more heterogeneous nature and 418 with a diameter of about $3 \mu \mathrm{m}$, showed gypsum as one of the main constituents of the 419 particle, but also the presence of fluorine (around $22 \%$ in weight). The origin of the 420 fluorine is not clear. Fluorides are naturally occurring components (in rocks, soils, etc.) 421 and they can enter the atmosphere through volcanic emissions and the re-suspension of 422 soil by the wind. Marine aerosols also release small amounts of gaseous hydrogen 423 fluoride and fluoride salts into the air (Franzén 1990; Stefanis et al. 2005). Moreover, it 424 may come from anthropogenic sources such as industry, incinerators, etc. Indeed, 425 fluorine identified on the surface of a building located in Getxo, may come from a 426 factory (where fluorine compounds are produced), as has been reported (Martínez427 Arkarazo et al. 2007).

428 With regard to the metallic elements distribution, the predominant element was found to 429 be iron as is depicted in Figure 6C (Fe particles are highlighted in blue). This spot was 430 considered as representative of the sample as this behavior is extended along the 431 surface. These maps contribute to know the way in which metallic particles are 432 deposited. At this spot, Mn, Fe and Ti-rich particles are shown. Iron is clearly the most 433 abundant element, being deposited in a wide range of different particle sizes, which 434 range from $1 \mu \mathrm{m}$ long to a diameter of 20-25 $\mu \mathrm{m}$ approximately. The EDS spectrum of 435 the Fe particle particularly, revealed the contribution of other metals such as $\mathrm{Zn}$ and 436 traces of $\mathrm{Pb}$ (see Figure 6F).

437 In addition to $\mathrm{Fe}$, titanium particles with acicular shape of $20 \mu \mathrm{m}$ long approximately 438 can be observed (see Figure 6C). And finally, manganese is present in a minor extent 439 with an average size of around $5 \mu \mathrm{m}$. The EDS spectrum of the Mn particle revealed 440 that it is composed mainly of $\mathrm{Mn}$, without any contribution of other metals, in 441 contradiction to the cases of other aggregates.

442 Thanks to the EDS maps, through correlation of the elements, it was possible to 
443 evaluate the different kinds of depositions apart from those mentioned before. On the

444 one hand, the influence of marine aerosol is obvious. The EDS maps of $\mathrm{Na}, \mathrm{Cl}$ and also

$445 \mathrm{Mg}$ are quite coincident, suggesting deposition of halite $(\mathrm{NaCl})$ and $\mathrm{MgCl}$ (see Figure

446 S3 from Supplementary Material). Moreover, in some microscopic areas from the Na 447 and $\mathrm{Cl}$ EDS maps, both elements distribution is coincident pointing out the presence of 448 halite $(\mathrm{NaCl})$ crystal (see Figure S3 from Supplementary Material). On the other hand, 449 the depositions of aluminosilicates are shown in the EDS maps of Al and Si (see Figure 450 S3 from Supplementary Material). Furthermore, the distribution of Fe and Ti, highlight 451 again the high rate of metallic depositions on the sample (see Figure S3 from 452 Supplementary Material). Finally, the $\mathrm{C}$ map showed an accumulation, which indicates 453 the presence of carbonaceous particles, probably corresponding to soot (see Figure S3 454 from Supplementary Material).

455 In order to perform a comparative analysis of the elemental composition from each 456 representative crust extracted from the three buildings, three selected areas from each 457 crust sample (one from each building) were analyzed by EDS. For each crust sample, 458 the semi-quantitative information from the three selected areas was obtained and an 459 average value was calculated for each building crust sample. In Figure 7 a 460 representative SEM image of each building crust sample is shown together with the 461 semi-quantitative values (average) obtained from each building crust sample. The 462 results pointed out that the major concentration of sulfur was present in the cemetery 463 gate's black crust. Hence, it is assumed that the limestone of the cemetery has been 464 exposed to an atmosphere rich in $\mathrm{SO}_{\mathrm{x}}$ acid aerosols for a longer period of time 465 comparing with the rest of the building, with the proper conditions to commence an 466 important sulfation process, enhancing in this way the formation of crystals that are, 467 doubtless, the best formed crystals comparing to the rest of the samples in terms of size 468 and crystal structure (see SEM image 3 In Figure 7 showing the sulfate crystals from the cemetery gate's black crust in comparison with the crusts of the other two buildings).

\section{Conclusions}

473 Through the evaluation of the different patterns of weathering processes -all due to 474 atmospheric influence- among the analyzed façades, it was determined that the 475 presence of sulfates was massive in the case of limestone's black crusts and minor in the 
476 case of other materials. Despite the minor presence of sulfates, the hazardousness of the

477 identified anhydrite plays a crucial role in the soiling of Talaieta street building due to

478 the dissolution/precipitation processes that can suffer this kind of sulfate.

479 All the cases showed the influence of marine aerosols, being the case of Talaieta street 480 building the most affected one. In this case, the contribution of marine aerosols may 481 have played a negative role in the formation of the crust (contribution of airborne 482 particulate matter).

483 Carbonaceous particles associated to the nearby preexisted railway and road traffic were 484 found in a great extent in the crusts formed on the sandstone from the Malacate 485 building. These particles have formed a smooth compact layer over the gypsum crystals 486 of the crust.

487 Regarding the rate of depositions, the most recently constructed building is the most 488 affected by the depositions of airborne particulate matter, depicting the highest 489 susceptibility (among the studied substrates) that have been ascribed to the low quality 490 of the building material associated to the high percentage of aluminosilicates in the 491 substrate.

492 The Malacate construction has been exposed to a polluted atmosphere rich in $\mathrm{SO}_{\mathrm{x}}$ and 493 iron particles, as the advanced stages of the crusts indicates the presence of hematite, 494 magnetite and (para)coquimbite.

495 The cemetery gate has undergone the formation of a crust, which also hosts 496 microorganisms/colonizers, depicting a complex black crust matrix.

497 The use of molecular and elemental spectroscopic techniques allowed the determination 498 of the degradation state of the substrates due to the formation of soiling and black 499 crusts. Moreover, micro-Raman spectroscopy together with SEM/EDS has proven to be 500 a reliable combination for the assessment of the depositions of airborne particulate 501 matter and the degradation products formed due to the impact of atmospheric pollutants, 502 as well as any other inputs such as graffiti for example.

503 The use of micro-Raman spectroscopy results in a valuable resource for this kind of 504 crusts, especially regarding the characterization of crustal particulate matter such as 505 hematite and magnetite, feldspars such adularia, sanidine and other kind of Al-silicates 
506 as well as calcium sulfates.

507

\section{Acknowledgements}

509 This work has been funded by the Spanish Ministry of Economy and Competitiveness 510 (MINECO) through the project DISILICA-1930 (ref.BIA2014-59124-P) and the 511 Regional Development Fund (FEDER). E. Calparsoro is grateful also to Spanish 512 Ministry of Economy and Competitiveness (MINECO) who funded his pre-doctoral 513 fellowship (ref: BES-2014-068940). Technical support provided by the Raman514 LASPEA laboratory of the SGIker (UPV/EHU, MICINN, GV/EJ, ERDF and ESF) is 515 also gratefully acknowledged.

\section{References}

518 Barca D, Belfiore CM, Crisci GM, La Russa MF, Pezzino A, Ruffolo SA (2010) 519 Application of laser ablation ICP-MS and traditional techniques to the study of black 520 crusts on building stones: a new methodological approach. Environ Sci Poll Research $521 \quad 17: 1433-1447$

522 Barca D, Belfiore CM, Crisci GM, La Russa MF, Pezzino A, Ruffolo SA (2011) A new 523 methodological approach for the chemical characterization of black crusts on building 524 stones: a case study from the Catania city centre (Sicily, Italy). J Anal At Spectrom $525 \quad 26: 1000-1011$

526 Barca D, Comite V, Belfiore C.M, Bonazza A, La Russa M.F, Ruffolo S.A, Crisci G.M, 527 Pezzino A, Sabbioni C (2014) Impact of air pollution in deterioration of carbonate 528 building materials in Italian urban environments. App Geochem 48:122-131

529 Bonazza A, Brimblecombe P, Grossi CM, Sabbioni C (2007) Carbon in Black Crusts 530 from the Tower of London. Environ Sci Technol 41:4199-4204

531 Brimblecombe P, Grossi CM (2005) Aesthetic thresholds and blackening of stone 532 buildings. Sci Total Environ 349:175-189 
533 Charola A, Pühringer J, Steiger M (2007) Gypsum: a review of its role in the 534 deterioration of building materials. Environ Geol 52:339-352

535 Comodi P, Kurnosov A, Nazzareni S, Dubrovinsky L (2012) The dehydration process 536 of gypsum under high pressure. Phys Chem Miner 39:65-71

537 Crupi V, Allodi V, Bottari C, D’Amico F, Galli G, Gessini A, La Russa M.F, Longo F, 538 Majolino D, Mariotto G, Masciovecchio C, Pezzino A, Rossi B, Ruffolo S.A, Venuti V 539 (2016) Spectroscopic investigation of Roman decorated plasters by combining FT-IR, 540 micro-Raman and UV-Raman analyses. Vib Spectrosc 83:78-84

541 Doehne E, Price CA (2011) Stone Conservation: An Overview of Current Research, 542 Second edition. Getty Conservation Institute.

543 Downs RT, Hall-Wallace M (2002) 18th General Meeting of the International 544 Mineralogical Association, Edinburgh, Scotland. Programme With Abstracts, 128

545 EPA 2016 https://www.epa.gov/pm-pollution [last accessed July 2016]

546 Espinosa-Marzal R.M, Scherer G.W (2010) Advances in Understanding Damage by 547 Salt Crystallization. Acc Chem Res 43;897-905

548 Flatt R.J (2002) Salt damage in porous materials: how high supersaturations are 549 generated. J Cryst Growth 242:435-454Franzén, LG (1990) Transport, deposition and 550 distribution of marine aerosols over southern Sweden during dry westerly storms. 551 Ambio 180-188

552 Gautam P, Blaha U, Appel E (2005) Magnetic susceptibility of dust-loaded leaves as a 553 proxy of traffic-related heavy metal pollution in Kathmandu city, Nepal. Atmos Environ $554 \quad 39: 2201-2211$

555 Gómez-Nubla L, Aramendia J, Fdez-Ortiz de Vallejuelo S, Castro K, Madariaga J.M 556 (2013) From Portable to SCA Raman devices to characterize harmful compounds 557 contained in used black slag produced in Electric Arc Furnace of steel industry. J 558 Raman Spectrosc 44:1163-1171

559 ICOMOS, 2008. http://www.icomos.org/en/component/content/article/116-english560 categories/resources/publications/261-monumentsasites-Xv. [last accessed July 2016] 
561 Inza-Agirre A (2010) Estudio de series temporales y composición química del material 562 particulado atmosférico en distintas áreas del País Vasco. Thesis, Universidad del País 563 Vasco UPV/EHU

564 Larssen T, Lydersen E, Tang D, He Y, Gao J, Liu H, Duan L, Seip HM, Vogt RD, 565 Mulder J, Shao M, Wang Y, Shang H, Zhang X, Solberg S, Aas W, Okland T, Eilertsen 566 O, Angell V, Li Q, Zhao D, Xiang R, Xiao J, Luo J (2006) Acid Rain in China. Environ 567 Sci Technol 40:418-425

568 Maguregui M, Sarmiento A, Martínez-Arkarazo I, Angulo M, Castro K, Arana G, 569 Etxebarria N, Madariaga JM (2008) Analytical diagnosis methodology to evaluate 570 nitrate impact on historical building materials. Anal Bioanal Chem 391:1361-1370

571 Maguregui M, Sarmiento A, Escribano R, Martinez-Arkarazo I, Castro K, Madariaga 572 JM (2009) Raman spectroscopy after accelerated ageing tests to assess the origin of 573 some decayed products found in real historical bricks affected by urban polluted 574 atmospheres. Anal Bioanal Chem 395:2119-2129

575 Maguregui M, Prieto-Taboada N, Trebolazabala J, Goienaga N, Arrieta N, Aramendia J, 576 Gomez-Nubla L, Sarmiento A, Olivares M, Carrero JA, Martinez-Arkarazo I, Castro K, 577 Arana G, Olazabal MA, Fernandez LA, Madariaga JM (2010a) CHEMCH 1st 578 international congress chemistry for cultural heritage, Ravenna

579 Maguregui M, Knuutinen U, Castro K, Madariaga JM (2010b) Raman spectroscopy as a 580 tool to diagnose the impact and conservation state of Pompeian second and fourth style 581 wall paintings exposed to diverse environments (House of Marcus Lucretius). J Raman 582 Spectrosc 41:1400-1409

583 Maguregui M, Knuutinen U, Martínez-Arkarazo I, Castro K, Madariaga JM (2011) 584 Thermodynamic and Spectroscopic Speciation to Explain the Blackening Process of 585 Hematite Formed by Atmospheric SO2 Impact: The Case of Marcus Lucretius House 586 (Pompeii). Anal Chem 83:3319-3326

587 McAlister JJ, Smith BJ, Török A (2008) Transition metals and water-soluble ions in 588 deposits on a building and their potential catalysis of stone decay. Atmos Environ $589 \quad 42: 7657-7668$ 
590 Morillas H, Maguregui M, García-Florentino C, Carrero JA, Madariaga JM (2016a) The 591 cauliflower-like black crusts on sandstones: A natural passive sampler to evaluate the surrounding environmental pollution. Environ Res 17:218-232

593 Morillas H, García-Galán J, Maguregui M, García-Florentino C, Marcaida I, Madariaga 594 J.M (2016b) In-situ multianalytical methodology to evaluate the conservation state of 595 the entrance arch of La Galea Fortress (Getxo, north of Spain). Microchem J 128:288$596 \quad 296$

597 Morillas H, García-Galán J, Maguregui M, Marcaida I, García-Florentino C, Carrero 598 J.A, Madariaga J.M (2016c) Evaluation of marine and urban-industrial environments 599 influence on the conservation state of sandstone in Cultural Heritage Monuments using 600 Handheld Energy Dispersive X-ray Fluorescence and other laboratory techniques. 601 Spectroschim Acta B 123:76-88

602 Morillas H, Marcaida I, Maguregui M, Carrero JA, Madariaga JM (2016d) The 603 influence of rainwater composition on the conservation state of cementitious 604 building materials. Sci Total Environ 542:716-727

605 Morillas H, Maguregui M, García-Florentino C, Marcaida I, Madariaga JM (2016e) 606 Study of particulate matter from Primary/Secondary Marine Aerosol and 607 anthropogenic sources collected by a self-made passive sampler for the evaluation 608 of the dry deposition impact on built heritage. Sci Total Environ 550:285-296

609

610 Moropoulou A, Bisbikou K, Torfs K, Van Grieken R, Zezza F, Macri F (1998) Origin 611 and growth of weathering crusts on ancient marbles in industrial atmosphere. Atmos 612 Environ 32:967-982

613 Potgieter-Vermaak SS, Godoi RHM, Grieken RV, Potgieter JH, Oujja M, Castillejo M 614 (2005) Micro-structural characterization of black crust and laser cleaning of building 615 stones by micro-Raman and SEM techniques. Spectrochim. Acta A 61:2460-2467

616 Prieto-Taboada N, Gómez-Laserna O, Martinez-Arkarazo I, Olazabal MA, Madariaga 617 JM (2014) Raman spectra of the Different Phases in the $\mathrm{CaSO}_{4}-\mathrm{H}_{2} \mathrm{O}$ system. Anal 618 Chem 86:10131-10137 
619 Querol X, Moreno T, Alastuey A, Gibbons W (2011) Geoquímica Inorgánica 620 Atmosférica: Elementos Trazadores de Fuentes Emisoras de Contaminantes. Macla $621 \quad 14: 143-144$

622 Rodríguez-Navarro C, Doehne E, Sebastian E (2000) How does sodium sulfate 623 crystallize? Implications for the decay and testing of building materials. Cement 624 Concrete Res 30:1527-1534

625 Ruffolo S.A, Comite V, La Russa M.F, Belfiore C.M, Barca D, Bonazza A, Crisci G.M, 626 Pezzino A, Sabbioni C (2015) An analysis of the black crusts from the Seville 627 Cathedral: A challenge to deepen the understanding of the relationships among 628 microstructure, microchemical features and pollution sources. Sci Tot Environ 502:157$629 \quad 166$

630 Saiz-Jimenez C, Garcia del Cura M.A (1991) Sulfated crusts: a microscopic, inorganic 631 and organic analysis. In Science, Technology and European Cultural Heritage, ed. N.S. 632 Baer, C. Sabbioni, A.I. Sors, Oxford, UK, Buttenworth-Heinemann 527-534

633 Sarmiento A, Maguregui M, Martinez-Arkarazo I, Angulo M, Castro K, Olazábal MA, 634 Fernández LA, Rodríguez-Laso MD, Mujika AM, Gómez J, Madariaga JM (2008) 635 Raman spectroscopy as a tool to diagnose the impacts of combustion and greenhouse 636 acid gases on properties of Built Heritage. J Raman Spectrosc 39:1042-1049

637 Schiavon N, Chiavari G, Fabbri D (2004) Soiling of limestone in an urban environment 638 characterized by heavy vehicular exhaust emissions. Environ Geol 46:448-455

639 Stefanis A, Theoulakis P, Pilinis C, (2005) The decay effects of sea-salt aerosol on the 640 surface of historic buildings. Proceedings of the 9th International Conference on 641 Environmental Science and Technology Rhodes island, Greece A1391-A1396

642 Sýkorová I, Havelcová M, Zeman A, Trejtnarová H (2011) Carbon air pollution 643 reflected in deposits on chosen building materials of Prague Castle. Sci Total Environ 644 409:4606-4611.

645 Watson JG, Chow JC, Chen LWA (2005) Summary of organic and elemental 646 carbon/black carbon analysis methods and intercomparisons. Aerosol Air Qual Res $647 \quad 5: 65-102$ 
648 Wein J, Wang A, Lambert JL, Wettergreen D, Cabrol NA, Warren-Rhodes K (2014)

649 Mars Microbeam Raman Spectrometer (MMRS) on-board the Zöe Rover in the 650 Atacama" in $11^{\text {th }}$ International GeoRaman Conference, St. Louis, USA 651

\section{FIGURE CAPTIONS}

653

654 Figure 1. (a) Detail of the sampling location, (b) Malacate building and detail of its 655 deteriorations patterns in sandstone, limestone and brick (from right to left), (c) Talaieta street 656 building and a zoom of the soiling process and (d) Cemetery and detail of black crusts on it.

657 Figure 1. Raman spectra of samples of (A) Malacate's brick showing hematite, gypsum and 658 (para)coquimbite or $\gamma$-anhydrite, (B) Malacates's sandstone showing carbon and gypsum, (C) 659 Talaieta street's building showing hematite and (D) Talaieta street building showing anhydrite.

660 Figure 2. (A) SEM images of black crust on Malacate's sandstone showing a matrix of carbon 661 layer. (B) Zoom of gypsum crystals on the pore. (C) Zoom of a deposited particle. (D) EDS 662 spectrum depicting the main composition of Cl-particle in (C).

663 Figure 4. SEM image of the black crust on Malacate's limestone where the EDS punctual 664 analyses were carried out, showing an aggregate of salts (A), gypsum (B) and calcite (c).

665 Figure 5. (A) SEM image of the cemetery gate's black crust showing random depositions. (B) 666 Carbon EDS map highlighted in red (C) EDS spectra of selected particles on images A and (D) 667 the pie chart of semi-quantitative information about the composition of aggregate particle 4 668 obtained by EDS.

669 Figure 6. Soiling affected samples of Talaieta street building: (A) Ca EDS map (B) Si and S 670 EDS maps overlapped on the same microscopic area as A (C) metallic particles identified by 671 EDS on the same microscopic area (D) additional microscopic area focused with the SEM (E) 672 EDS analysis of the particle circled in (D) (F) EDS spectrum of Fe particles from Figure C.

673 Figure 7. SEM images and the corresponding semi-quantitative composition (Atomic \%) 674 acquired by EDS analysis. Samples corresponding, to the soiling of the building of Talaieta 675 street (1), black crust on the sandstone of the Malacate (2) and on the limestone of the cemetery 676 gate (3).

677 
Table 1. Summary of the main results obtained from the crust samples study.

\begin{tabular}{|c|c|c|c|c|}
\hline & Malacate sandstone & Malacate limestone & Cemetery gate & Talaieta buidling \\
\hline $\begin{array}{l}\text { Appearance } \\
\text { of the crust }\end{array}$ & $\begin{array}{l}\text { Smooth and compact } \\
\text { carbon layer with } \\
\text { pores from where the } \\
\text { underlaying gypsum } \\
\text { crystals are } \\
\text { observable }\end{array}$ & $\begin{array}{l}\text { Not as smooth and } \\
\text { compact carbon } \\
\text { layer }\end{array}$ & $\begin{array}{l}\text { A matrix of gypsum } \\
\text { crystals with } \\
\text { depositions of carbon } \\
\text { particles and particles } \\
\text { deposited randomly }\end{array}$ & $\begin{array}{l}\text { Brownish crust with not } \\
\text { so many gypsum crystals } \\
\text { and several randomly } \\
\text { arranged particles without } \\
\text { cohesion }\end{array}$ \\
\hline $\begin{array}{c}\text { Main } \\
\text { components }\end{array}$ & $\begin{array}{c}\text { Gypsum } \\
\text { Amorphous carbon } \\
\text { Hematite }\end{array}$ & $\begin{array}{c}\text { Gypsum } \\
\text { Amorphous carbon } \\
\text { Hematite } \\
\text { Magnetite }\end{array}$ & $\begin{array}{l}\text { Gypsum } \\
\text { Carotenoids } \\
\text { Hematite } \\
\text { Magnetite }\end{array}$ & $\begin{array}{c}\text { Gypsum } \\
\text { Aluminosilicates }\end{array}$ \\
\hline $\begin{array}{l}\text { Graffiti } \\
\text { remains }\end{array}$ & & $\begin{array}{c}\text { Phtalocyanine blue } \\
\text { Black diamond } \\
\text { Burnt sienna (?) }\end{array}$ & & Ultram \\
\hline $\begin{array}{c}\text { Nature of the } \\
\text { deposited } \\
\text { particles }\end{array}$ & $\begin{array}{c}\text { Aluminosilicates } \\
\text { Quartz } \\
\text { Calcite } \\
\text { Gypsum } \\
\text { Marine aerosol } \\
\text { particles }(\mathrm{Na}, \mathrm{K}, \mathrm{Mg} \\
\text { and } \mathrm{Cl})\end{array}$ & $\begin{array}{c}\text { Aluminosilicates } \\
\text { Quartz } \\
\text { Calcite } \\
\text { Gypsum } \\
\text { Particles coming } \\
\text { from marine aerosol } \\
\text { including }(\mathrm{Na}, \mathrm{K} \text {, } \\
\mathrm{Mg} \text { and } \mathrm{Cl})\end{array}$ & $\begin{array}{c}\text { Aluminosilicates } \\
\text { Sulfates } \\
\text { Marine aerosol } \\
\text { particles }(\mathrm{Na}, \mathrm{K}, \mathrm{Mg} \\
\text { and } \mathrm{Cl}) \\
\text { Metallic particles ( } \mathrm{Ti} \text {, } \\
\mathrm{Mn}, \mathrm{Fe} \text { and } \mathrm{Zn})\end{array}$ & $\begin{array}{c}\text { Alkali feldspars } \\
\text { Quartz } \\
\text { Calcite } \\
\text { Hematite } \\
\text { Magnetite } \\
\text { Carbonaceous particles } \\
\text { Marine aerosol particles } \\
\text { (Na, K, Mg and } \mathrm{Cl} \text { ) } \\
\text { Fluorine } \\
\text { Metallic particles }(\mathrm{Ti}, \mathrm{Cr} \text {, } \\
\text { V, Mn, Fe, } \mathrm{Cu}, \mathrm{Zn}, \mathrm{Pb}) \\
\end{array}$ \\
\hline
\end{tabular}

Table 2. Semi-quantitative composition (\% weight units) of deposited particles (see Figure 4) on the black crust of limestone from Malacate building obtained by means of EDS.

\begin{tabular}{|c|c|c|c|c|c|c|c|c|c|c|}
\hline SPECTRUM & C & O & Na & Mg & Al & Si & S & Cl & Ca & Fe \\
\hline A & 25.9 & 61.1 & 0.3 & 0.1 & 0.3 & 0.6 & 0.1 & 0.2 & 11.1 & 0.01 \\
\hline B & 19.5 & 64.1 & & & & & 5.4 & & 11.0 & \\
\hline C & & 85.0 & & & & & & & 15.0 & \\
\hline
\end{tabular}




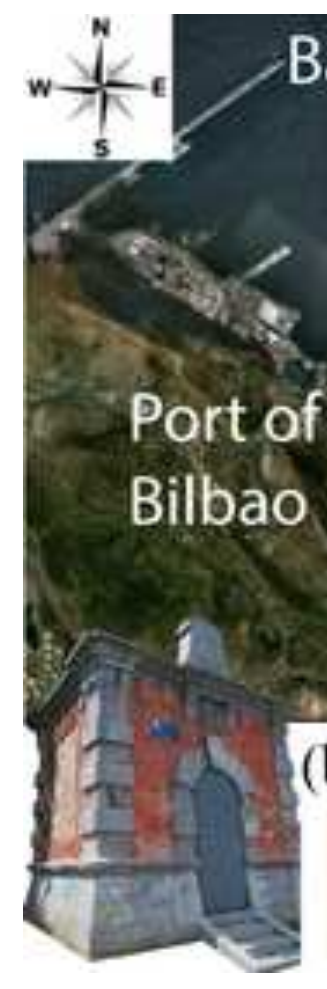

Bay of Biscay
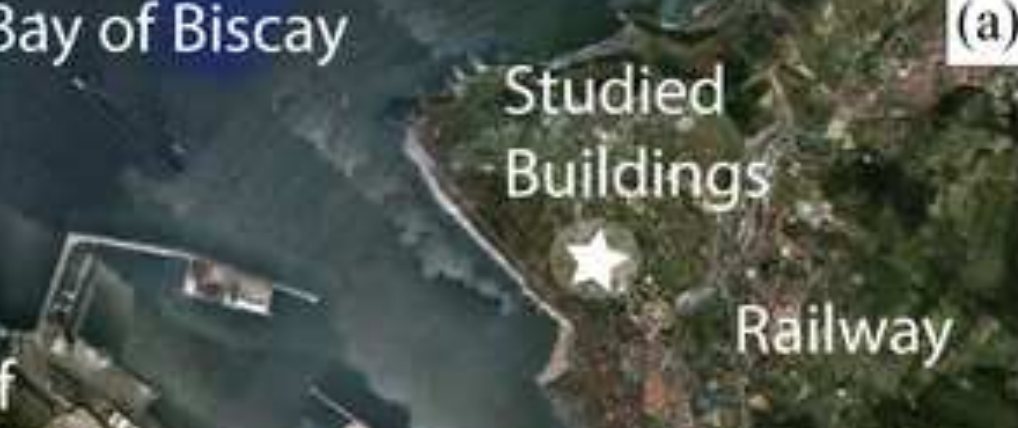

thes
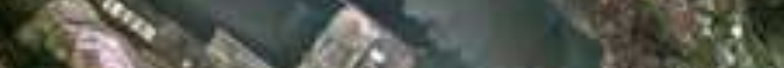

Industrial areas
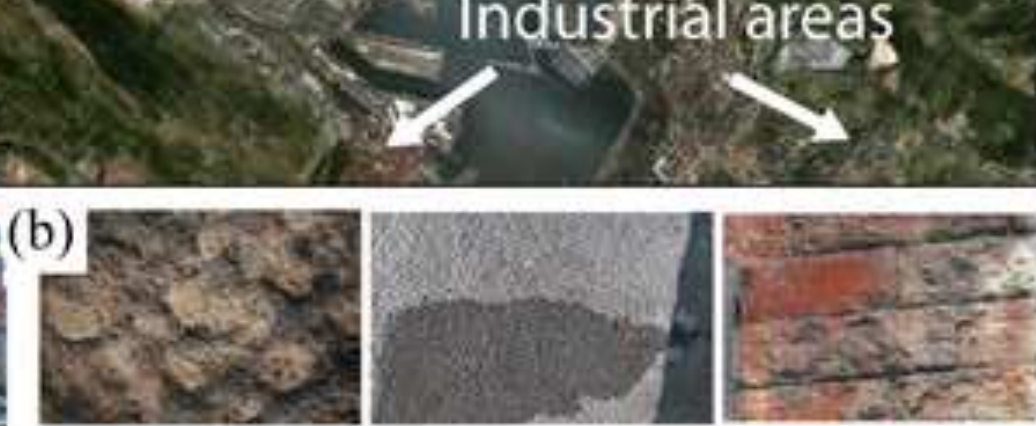

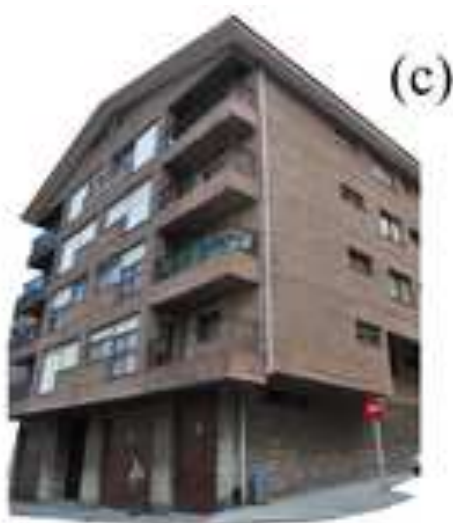

(c)
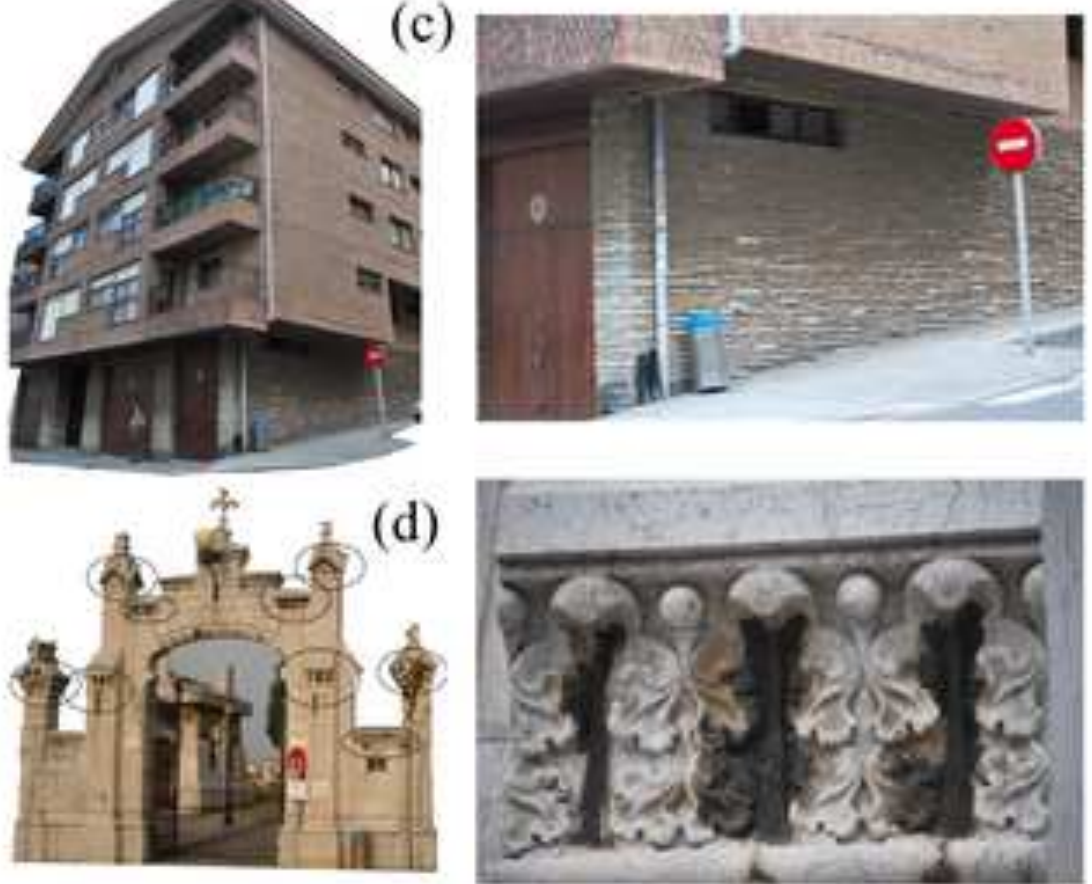

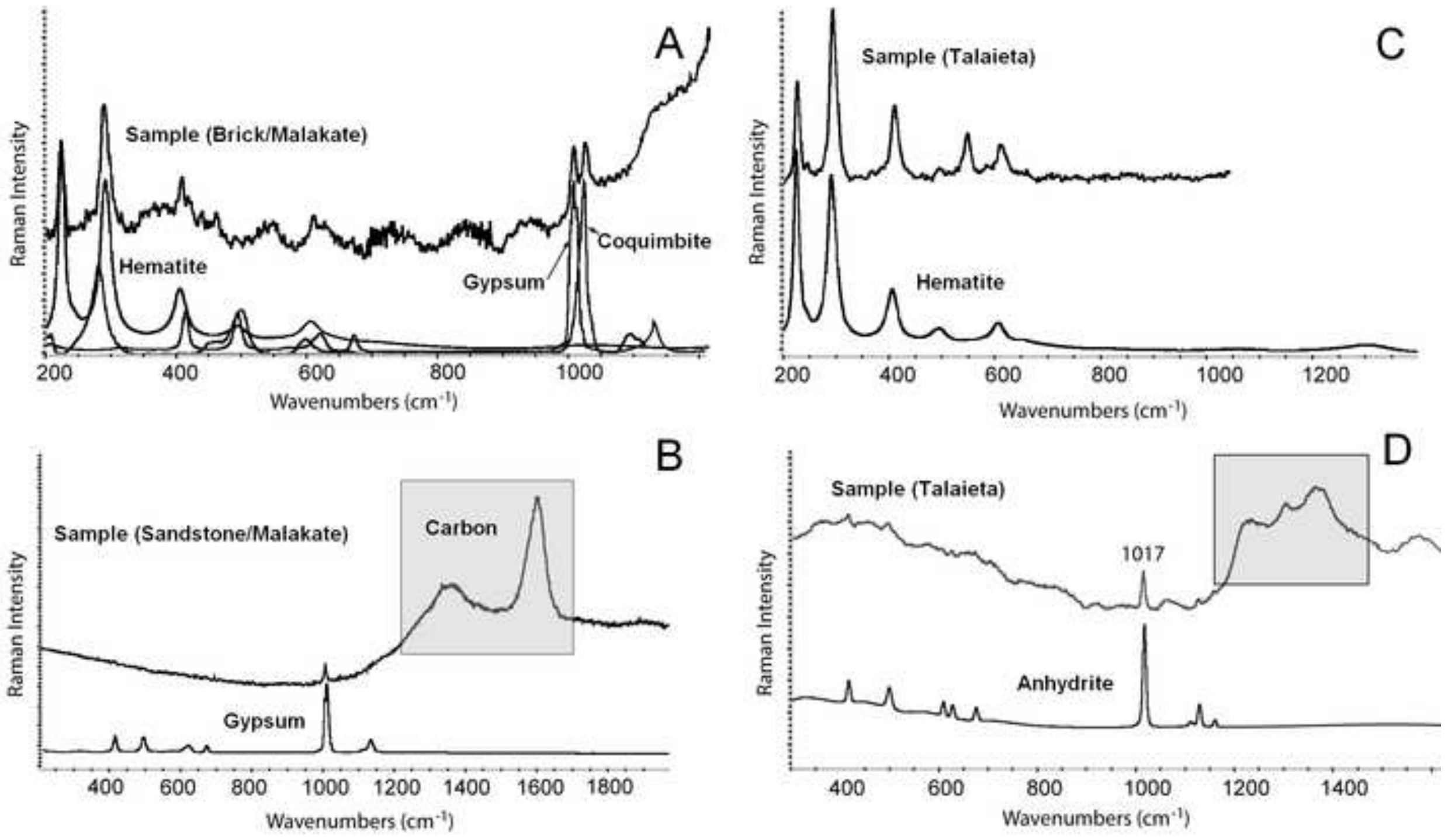


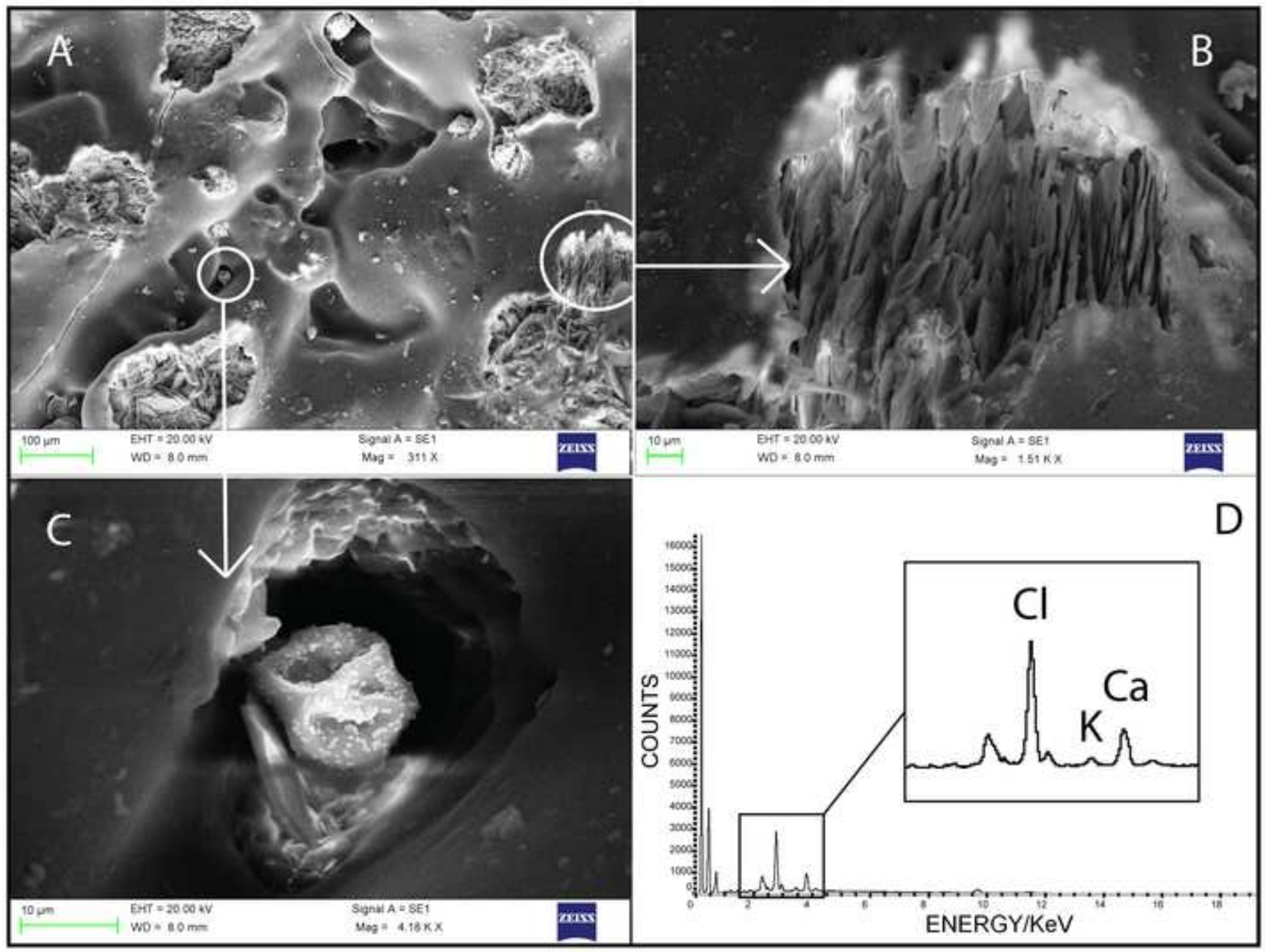



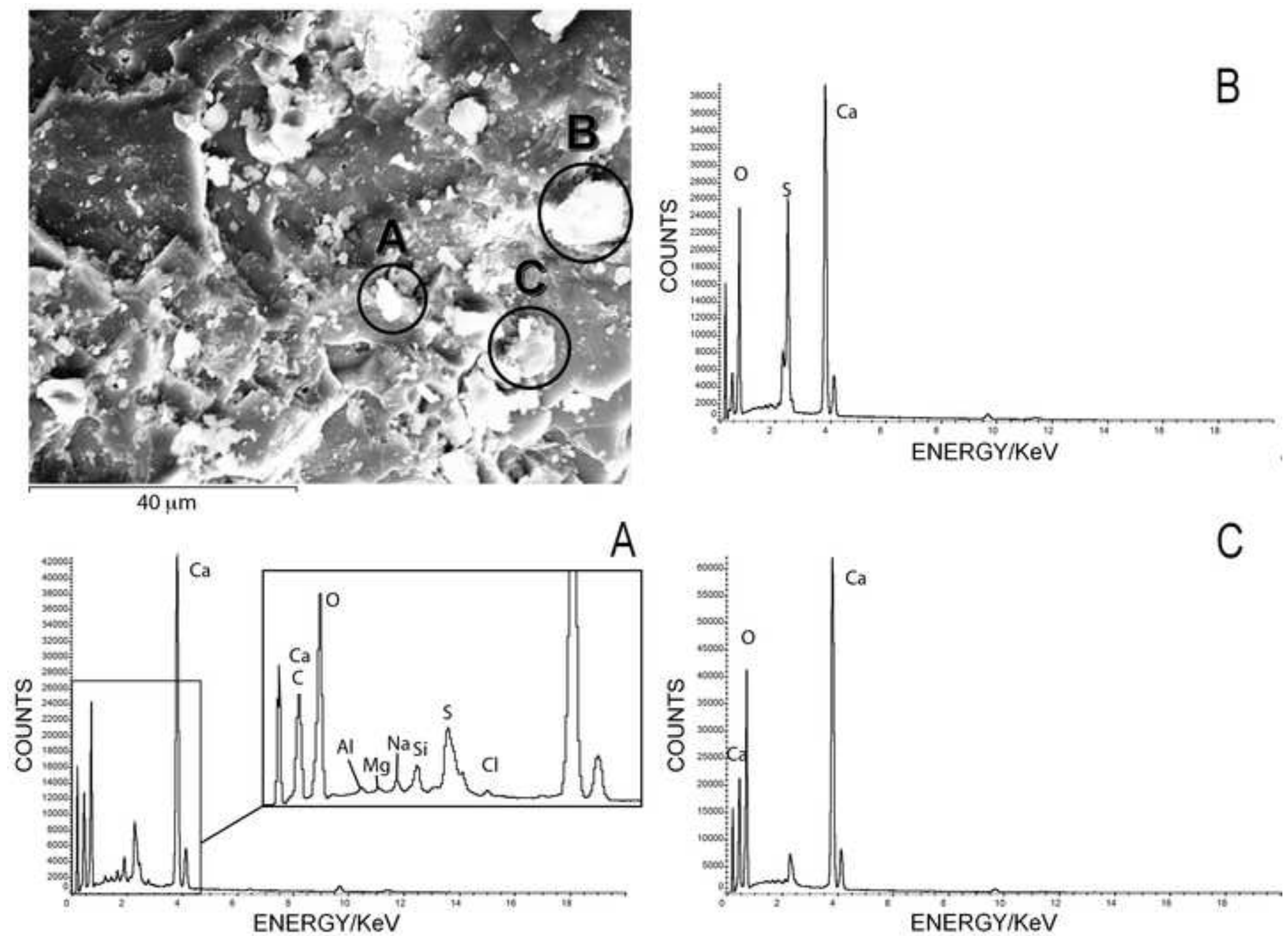

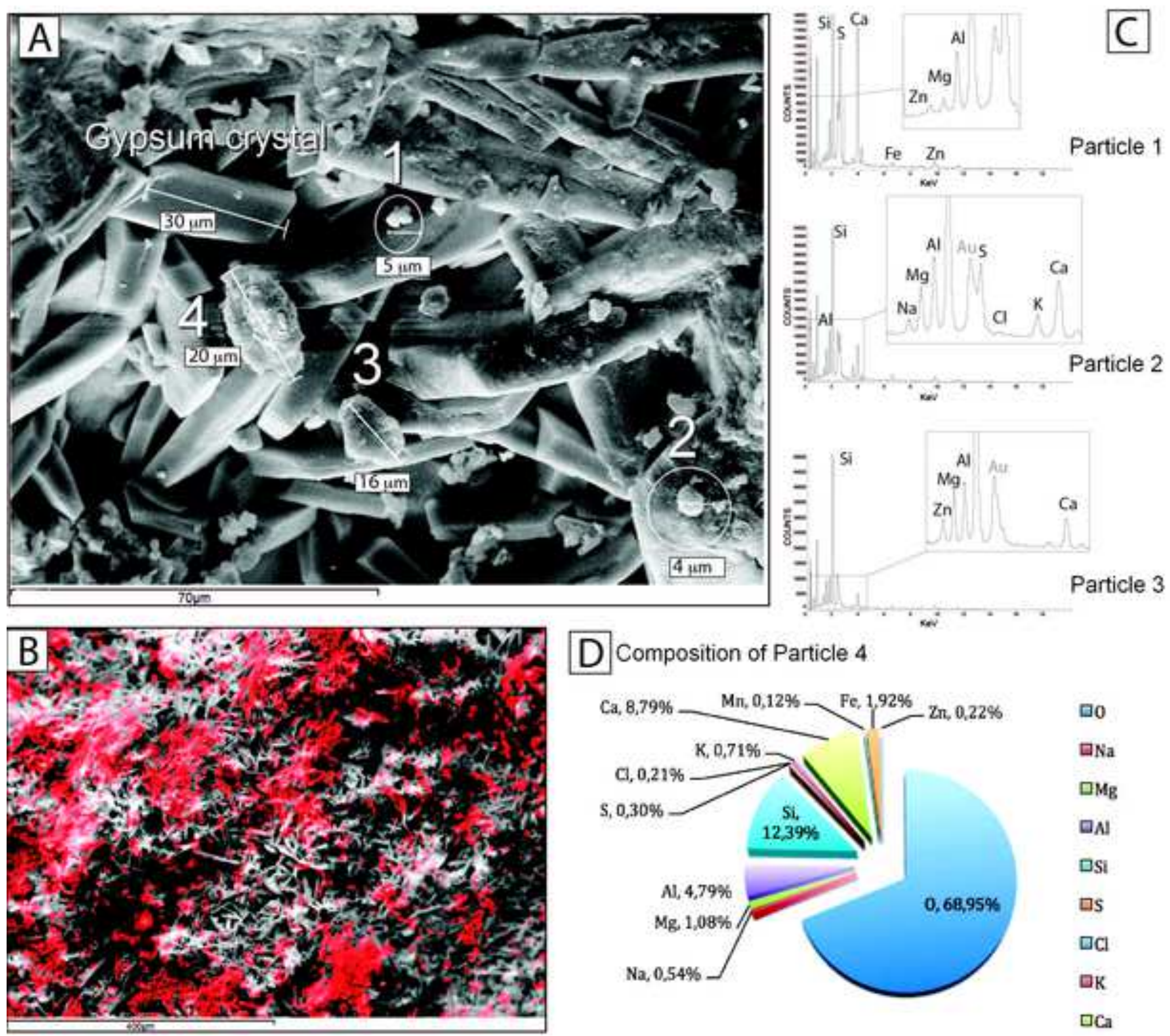

D Composition of Particle 4

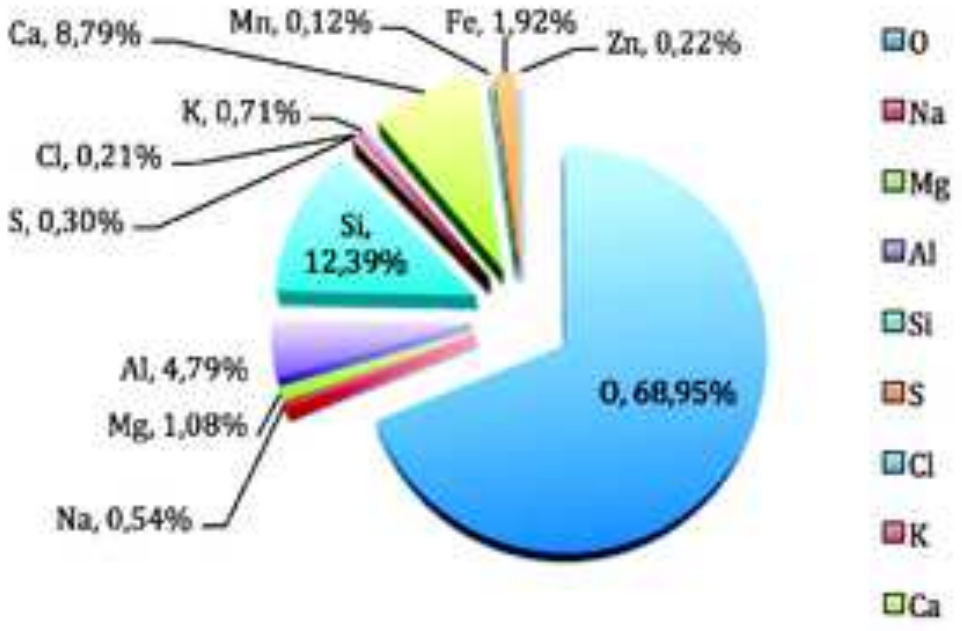

$\square_{\mathrm{Na}}$
$\square \mathrm{Mg}$
$\square_{\mathrm{Nl}}$
$\square \mathrm{Si}$
$\square S$
$\square \mathrm{Cl}$
$\square \mathrm{K}$
$\square \mathrm{Ca}$



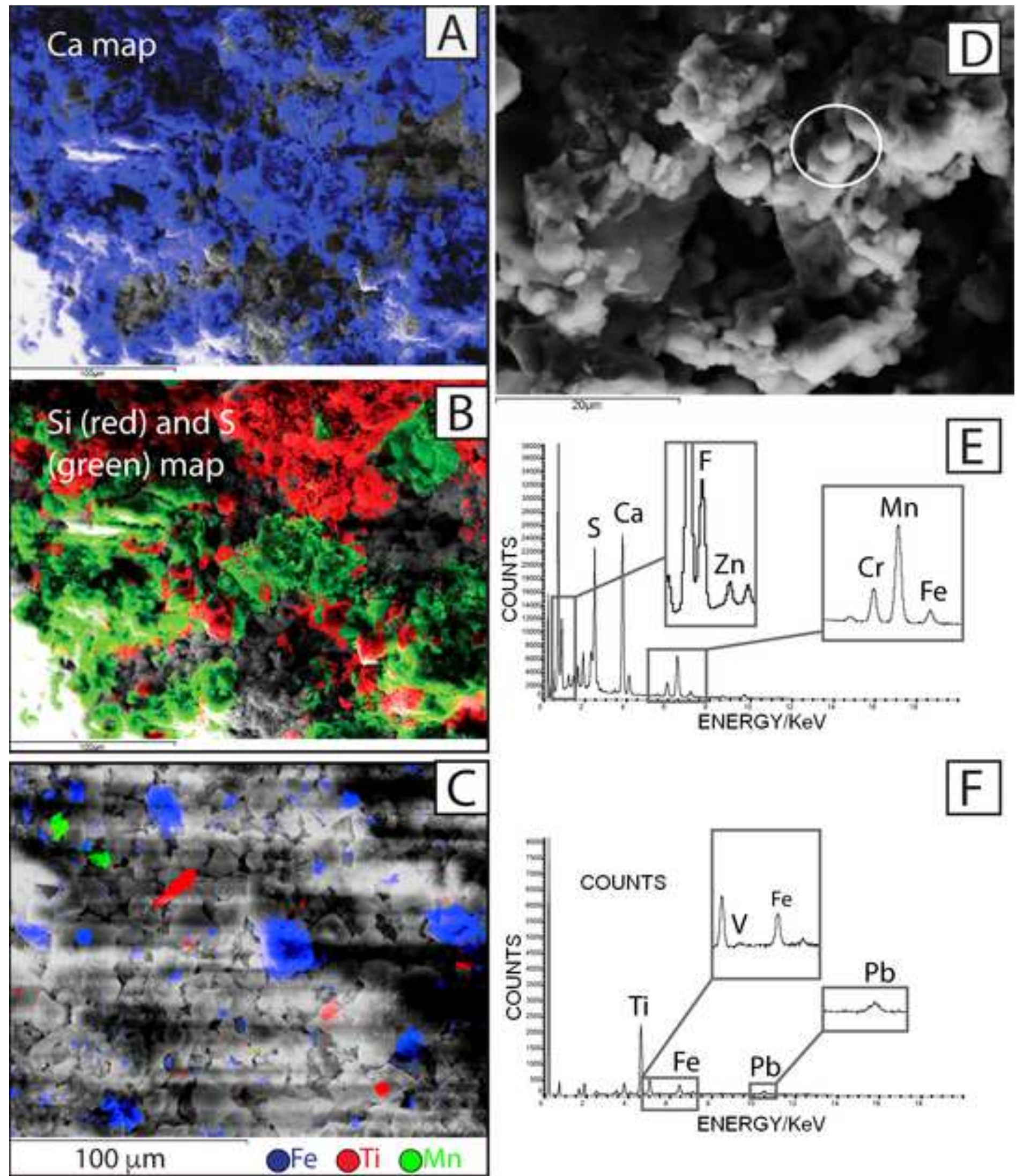

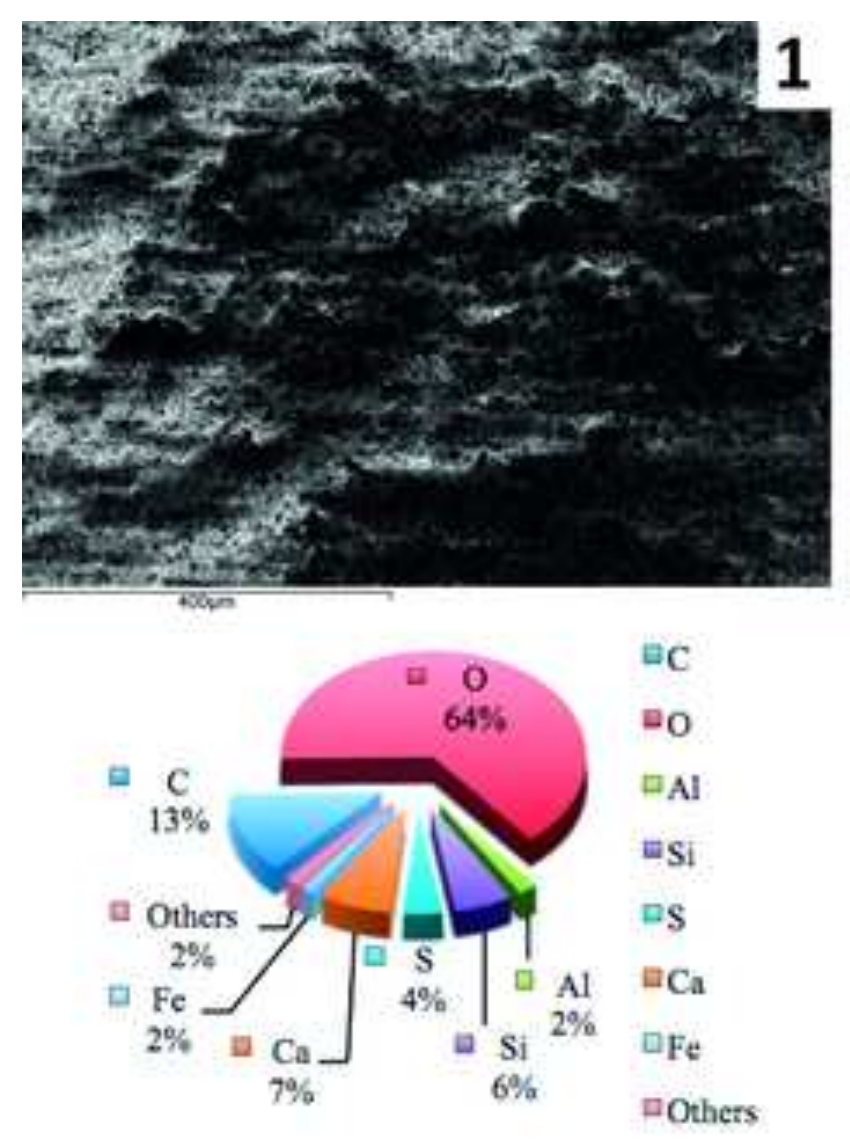
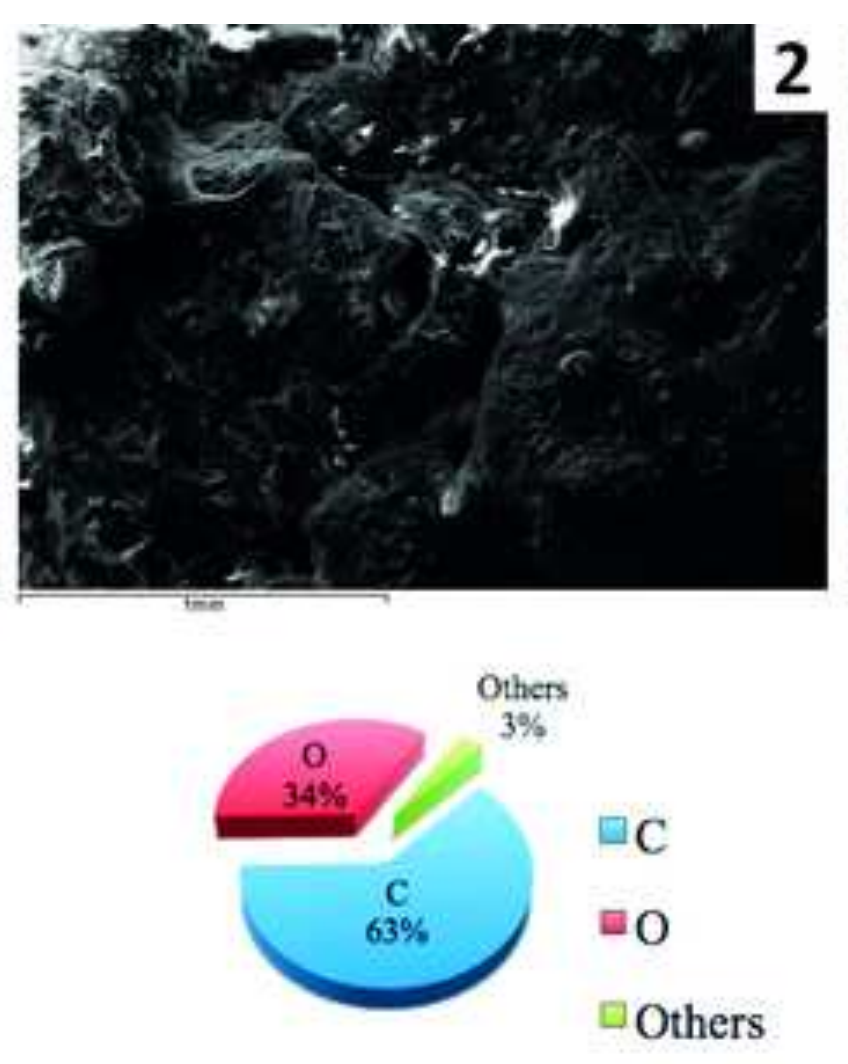
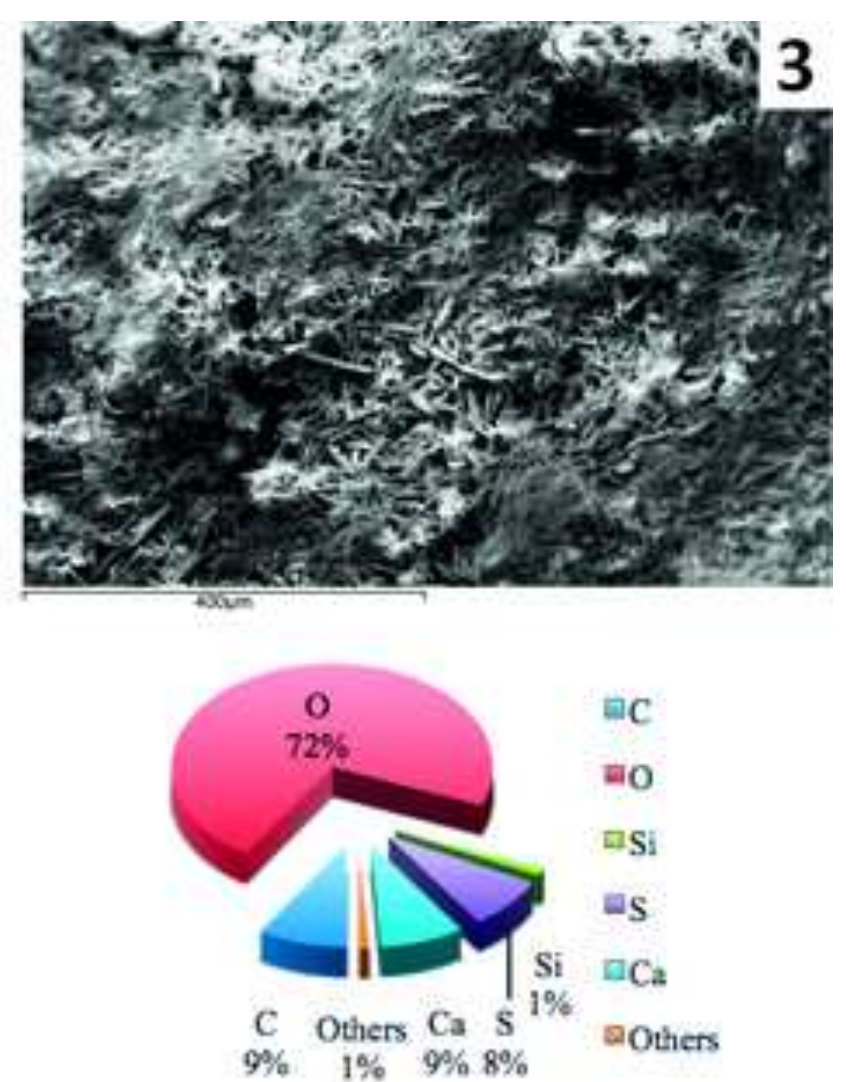